Urszula Pustułka-Piwnik ${ }^{1}$

Zdzisław Jan Ryn ${ }^{1}$

Łukasz Krzywoszański

Joanna Stożek ${ }^{1}$

\title{
BURNOUT SYNDROME IN PHYSICAL THERAPISTS - DEMOGRAPHIC AND ORGANIZATIONAL FACTORS
}

\author{
ZESPÓŁ WYPALENIA ZAWODOWEGO U FIZJOTERAPEUTÓW \\ A ZMIENNE DEMOGRAFICZNE I ORGANIZACYJNE
}

\author{
${ }^{1}$ University School of Physical Education / Akademia Wychowania Fizycznego, Kraków, Poland \\ Department of Clinical Rehabilitation / Katedra Rehabilitacji Klinicznej \\ ${ }^{2}$ Pedagogical University / Uniwersytet Pedagogiczny, Kraków, Poland \\ Department of Psychology / Katedra Psychologii
}

\begin{abstract}
Background: Professional burnout results from prolonged exposure to chronic, job-related stressors. According to Christina Maslach, professional burnout is a syndrome of emotional exhaustion, depersonalization and reduced personal accomplishment. Literature includes a number of reports on burnout syndrome within health service, but hardly ever do they make any references to physiotherapists. The purpose of this study is assessment of the level of professional burnout in a group of physiotherapists and investigating relationships between the indices of burnout syndrome and selected demographic as well as organizational variables. Material and Methods: The study group consisted of 151 physiotherapists with at least 3 years of experience, employed in various health service outposts in Krakow, Poland. The Maslach Burnout Inventory (MBI) was used to measure emotional exhaustion, depersonalization and personal accomplishment. A questionnaire for the description of socio-demographic and work characteristics was used as well. Results: Job burnout among the physiotherapists was manifested by an increased emotional exhaustion and decreased sense of personal achievement. Emotional exhaustion was significantly higher among physical therapists working with adults and employed in hospitals, depersonalization was higher among men, hospital workers and employees with seniority from 15 to 19 years, personal accomplishment was decreased among men and less-educated therapists. Conclusions: The study confirmed that indicators of burnout in physiotherapists are significantly associated with selected demographic and organizational variables. It is necessary to undertake a more exhaustive study of burnout in this group of employees, and implement elements of prevention. Med Pr 2014;65(4):453-462
\end{abstract}

Key words: burnout syndrome, Maslach Burnout Inventory, MBI, demographic and organizational characteristics, physical therapists

\section{STRESZCZENIE}

Wstęp: Wypalenie zawodowe powstaje w wyniku długotrwałej ekspozycji na stres związany z wykonywaną pracą. W ujęciu Christiny Maslach manifestuje się wyczerpaniem emocjonalnym, depersonalizacją i spadkiem poziomu osiągnięć osobistych. W literaturze jest wiele doniesień na temat wypalenia zawodowego w służbie zdrowia, ale nieliczne z nich dotyczą badań prowadzonych wśród fizjoterapeutów. Celem pracy jest ocena poziomu wypalenia zawodowego w grupie fizjoterapeutów i zbadanie związku między wskaźnikami wypalenia a wybranymi zmiennymi demograficznymi i organizacyjnymi. Materiał i metody: Grupę badaną stanowiło 151 fizjoterapeutów z co najmniej 3-letnim stażem pracy. Ankietowani byli zatrudnieni w placówkach służby zdrowia na terenie miasta i gminy Kraków. Do oceny wypalenia zawodowego zastosowano Kwestionariusz Wypalenia Zawodowego Christiny Maslach (Maslach Burnout Inventory - MBI). Wykorzystano także ankietę obejmująca zmienne demograficzne i organizacyjne. Wyniki: Wypalenie zawodowe w badanej grupie manifestowało się podwyższeniem poziomu wyczerpania emocjonalnego i spadkiem zadowolenia z osiągnięć osobistych. Wyczerpanie emocjonalne było istotnie wyższe u fizjoterapeutów pracujących z osobami dorosłymi i zatrudnionych w szpitalach. Depersonalizacja osiągnęła wyższy poziom u mężczyzn, pracowników szpitali i osób z 15-19-letnim stażem pracy. Poczucie osiągnięć osobistych było obniżone u mężczyzn i terapeutów z niższym poziomem wykształcenia. Wnioski: Badanie potwierdziło, że wskaźniki wypalenia zawodowego u fizjoterapeutów są istotnie związane z wybranymi zmiennymi demograficznymi i organizacyjnymi. Wskazane jest podjęcie bardziej wnikliwych badań wypalenia zawodowego w tej grupie pracowników i wdrożenie profilaktyki. Med. Pr. 2014;65(4):453-462

Słowa kluczowe: zespół wypalenia zawodowego, Kwestionariusz Wypalenia Zawodowego Christiny Maslach, MBI, zmienne demograficzne i organizacyjne, fizjoterapeuci

Corresponding author / Autorka do korespondencii: Urszula Pustułka-Piwnik, Department of Clinical Rehabilitation, University School of Physical Education, Jana Pawła II 78, 31-571 Kraków, Poland, e-mail: upustulka-piwnik@wp.pl Received: 2013, December 2, accepted: 2014, March 10 


\section{INTRODUCTION}

According to Christina Maslach, professional burnout is a syndrome of emotional exhaustion, depersonalization and reduced personal accomplishment (1). Emotional exhaustion is characterized by tiredness, lack of vigour or drive, higher irritability and a variety of psychosomatic symptoms. Depersonalization means a tendency towards distancing oneself during interpersonal contact. In the case of medical occupations, this might be manifested in a loss of empathy, "labelling" patients and treating them as another "medical case." Reduced perception of personal accomplishment manifests itself in a drop of an employee's feeling of competence and efficiency.

High level of burnout affects both the employee and the whole organization. Personnel absence and frequent sick leaves negatively impact the quality of health care, whereas overburdening other members of the therapeutic team elevates the risk of making medical blunders. Such a sense of burnout leads to a decrease in involvement in performing work, which results in earlier retirement or resigning from one's profession $(2,3)$.

Studies carried out among health professionals, including physiotherapists, suggest that burnout results from prolonged exposure to stress $(1,4)$. Sources of occupational stress are repeatedly seen in the nature of organizational factors. Most frequently mentioned aggravating factors in the professional work of a physiotherapist include the following: lack of professional autonomy, poor work organization, lack of equipment and staff, work overload or time pressure (5-7). Prevalence of stress and burnout may be contributed to inadequate gratification. Research shows that physiotherapists who experience imbalance between effort and reward had higher odds of being dissatisfied with their work (8).

Employees who work in health service are, undoubtedly, particularly exposed to specific strains which occur during work with ill people and those who need medical care. Physiotherapists, as well as other groups of professionals, are vulnerable to professional burnout because of their close interaction with patients. Effectiveness of the process of rehabilitation depends on emotional involvement of therapists and requires close physical contact with patients, frequently much closer than in the case of doctors or nurses (9). Similarly to other professions which consist of contact with humans, a physiotherapist's personality is somehow a working tool. Facing aggressive or depressive reactions of patients, stimulating their motivation as well as emotional and physical support might lead to overload.
Physiotherapists, similarly to other health professionals, are put at risk of a negative effect of work-related strain. There are some studies underlining physiotherapists' susceptibility to burnout syndrome (4,10-14).

Currently in Europe, including Poland, population aging is becoming a social problem (15). It brings about the necessity to expand retirement age as well as increases demand on the public health system $(16,17)$. This causes the people employed in this sector, including physiotherapists, to be increasingly forced to look after a growing group of the elderly, seriously ill and disabled people. Some research concurs that working with elders is related to great psychological stress of staff and is the source of job strain, which increases the risk of occurrence of job-related health problems and burnout $(8,18)$.

Consequently, a requirement arises to implement programmes aimed at preventing disorders resulting from job strain. The basis of such prevention programmes is hazard identification, i.e., assessment of working conditions in terms of their effect on human health. Considering changes connected with aging societies, it is important to identify factors that may affect the health and well-being of workers.

Although there are nearly 20000 physiotherapists employed in Poland, scientific output concerning occupational burnout among the professionals is insufficient. There is also lack of reliable evidence concerning consequences of strain typical for physiotherapists. The presented research is part of a wider project entitled "Psychological and occupational determinants of burnout syndrome in physiotherapists." The aim of this article is to investigate the level of burnout among physiotherapists and the relationships between the indices of burnout syndrome and selected demographic and work-related variables. The following research questions were posed:

1. What is the level of burnout among physiotherapists?

2. Is the severity of burnout in physiotherapists inconsistent due to demographic variables (age, sex, education level, family situation)?

3. Does the level of burnout indicators in physiotherapists vary due to the variables associated with the work?

\section{MATERIAL AND METHODS}

\section{Participants}

The study group consisted of physiotherapists employed in various health service outposts in Kraków, 
Poland. Subjects were recruited on a voluntary basis from a convenience sample of physiotherapists. All of the participants signed an agreement to contribute to the research. The following inclusion criteria were adopted: 3-year professional experience, a master's, bachelor's or technical degree in physiotherapy and direct contact with patients being under professional activity. The study included people who met these criteria and expressed their consent to participate.

The examination procedure was as follows. A letter asking for permission to carry out research and provide information on the number and job experience of employed physiotherapists was sent to 38 health care institutions. Basing on information from 33 institutions, a list of 352 physiotherapists who met the inclusion criteria was prepared. The subjects received a set of questionnaires in person, with detailed information regarding the purpose and nature of the research, and the project authors' data. After a week, completed questionnaires were collected from respondents in person. One hundred sixty physiotherapists consented to take part in the research. One hundred fifty one questionnaire sets that qualified were diligently and fully filled out.

\section{Questionnaires}

1. The Polish version of Maslach Burnout Inventory (MBI) for assessment of professional burnout (19). It is composed of 22 statements, comprising three scales: emotional exhaustion ( 9 items), depersonalization (5 items) and personal accomplishment (8 items). Respondents answer the question of how often they feel in a particular way on a 0-6 scale, where 0 indicates "never," and 6 means "daily."
Results are calculated for each of the subscales separately, according to the key. Burnout is confirmed by high results obtained on a subscale of emotional exhaustion (EE, 9-54 points) and depersonalization (DP, 5-30 points) and low results on a personal achievements subscale (PA, 8-48 points). This questionnaire has been validated in Polish and achieved the following alpha values for the scales: $\mathrm{EX}=0.85$, $\mathrm{DP}=0.60, \mathrm{PA}=0.76(19)$.

2. Authors' own questionnaire construction for the description of demographic and organizational data such as: gender, age, marital status, work experience, education, workplace and position.

\section{Statistical methods}

Statistical calculations were carried out using one-way analysis of ANOVA variance with the Tuckey HSD post-hoc test applied where appropriate. Significance was adopted at the level of $p<0.05$. Data analysis was performed using Statistica (version 10.0).

\section{RESULTS}

A detailed specification of the studied group is presented in Table 1. The study group consisted of 151 physiotherapists, aged 24-64. The average length of service in the profession was 14.11 years. The vast majority were women (86\%) and those married (67\%). More than half of the respondents had children. When considering education, $62 \%$ of the group members had a master's degree, while $38 \%$ were technicians and bachelors. All respondents were employed full-time. Over half of the participants (62\%) took on additional work, unsatisfied due to insufficient salaries.

\begin{tabular}{|c|c|c|c|}
\hline & \multirow[t]{2}{*}{$\begin{array}{l}\text { Variable } \\
\text { Zmienna }\end{array}$} & \multicolumn{2}{|c|}{$\begin{array}{c}\text { Respondents } \\
\text { Badani } \\
(\mathrm{N}=151)\end{array}$} \\
\hline & & $\mathrm{n}$ & $\%$ \\
\hline \multicolumn{4}{|c|}{ Age [years] / Wiek [w latach] } \\
\hline$<30$ & & 20 & 13.24 \\
\hline$>49$ & & 14 & 9.27 \\
\hline \multicolumn{4}{|l|}{ Sex / Płeć } \\
\hline female / kobieta & & 130 & 86.09 \\
\hline male / mężczyzna & & 21 & 13.91 \\
\hline
\end{tabular}


Table 1. Characteristics of the study group - cont.

Tabela 1. Charakterystyka badanej grupy - cd.

\begin{tabular}{|c|c|c|}
\hline \multirow[t]{2}{*}{$\begin{array}{c}\text { Variable } \\
\text { Zmienna }\end{array}$} & \multicolumn{2}{|c|}{$\begin{array}{c}\text { Respondents } \\
\text { Badani } \\
(\mathrm{N}=151)\end{array}$} \\
\hline & $\mathrm{n}$ & $\%$ \\
\hline \multicolumn{3}{|l|}{ Marital status / Stan cywilny } \\
\hline single / wolny & 40 & 26.49 \\
\hline married / żonaty/mężatka & 101 & 66.89 \\
\hline divorced / rozwiedziony/a & 10 & 6.62 \\
\hline \multicolumn{3}{|l|}{ Children / Dzieci [n] } \\
\hline 0 & 56 & 37.09 \\
\hline 1 & 40 & 26.49 \\
\hline 2 & 44 & 29.14 \\
\hline$\geq 3$ & 11 & 7.28 \\
\hline \multicolumn{3}{|l|}{ Education / Wykształcenie } \\
\hline technician, bachelor / technik, licencjat & 58 & 38.41 \\
\hline master of science / magister & 93 & 61.59 \\
\hline \multicolumn{3}{|l|}{ Work experience [years] / Staż pracy [w latach] } \\
\hline$<5$ & 13 & 8.61 \\
\hline $5-9$ & 41 & 27.15 \\
\hline $10-14$ & 33 & 21.86 \\
\hline $15-19$ & 28 & 18.54 \\
\hline$\geq 20$ & 36 & 23.84 \\
\hline \multicolumn{3}{|l|}{ Place of employment / Miejsce zatrudnienia } \\
\hline nursing home / dom opieki społecznej & 14 & 9.27 \\
\hline health centre / przychodnia & 38 & 25.17 \\
\hline sanatorium / sanatorium & 15 & 9.93 \\
\hline hospital / szpital & 84 & 55.63 \\
\hline \multicolumn{3}{|l|}{ Age group / Grupa wiekowa } \\
\hline adults / dorośli & 124 & 82.12 \\
\hline children / dzieci & 27 & 17.88 \\
\hline \multicolumn{3}{|l|}{ Workplace / Stanowisko pracy } \\
\hline physiotherapy department / dział fizykoterapii & 33 & 21.85 \\
\hline hospital ward / sala chorych & 24 & 15.89 \\
\hline gymnasium / sala gimnastyczna & 38 & 25.17 \\
\hline several of the above-mentioned places / kilka ww. miejsc & 56 & 37.09 \\
\hline
\end{tabular}

Due to the lack of Polish norms for the Maslach Burnout Inventory, results obtained in the present study were compared to the averages presented in the Polish adaptation by Pasikowski (19). Average values of burnout were also compared to the reference levels proposed by the authors of the MBI (20).
The significance of differences between burnout indicators obtained in the present study, and the values presented in the Polish adaptation of Pasikowski, were tested using the t-test for one sample (Table 2). The results indicated that emotional exhaustion among physiotherapists did not differ from the average of the standardization 
Table 2. Mean values for the indices of professional burnout in physiotherapists compared to the results of a standardization group Tabela 2. Średnie wartości wskaźników wypalenia zawodowego u fizjoterapeutów w porównaniu z wynikami próby standaryzacyjnej

\begin{tabular}{|c|c|c|c|c|c|c|}
\hline $\begin{array}{c}\text { Indice of professional burnout } \\
\text { Wskaźnik wypalenia zawodowego }\end{array}$ & $\begin{array}{c}\text { Level of indices } \\
\text { of burnout } \\
\text { Poziom wskaźników } \\
\text { wypalenia }^{1}\end{array}$ & M & $\mathrm{SD}$ & $\begin{array}{l}\text { Tested value } \\
\text { Testowana } \\
\text { wartość }{ }^{2}\end{array}$ & $\mathrm{t}$ & $\mathrm{p}$ \\
\hline Emotional exhaustion / Wyczerpanie emocjonalne(EW) & medium / średni & 20.58 & 10.86 & 20.42 & 0.184 & 0.854 \\
\hline Depersonalization / Depersonalizacja (DP) & low / niski & 5.98 & 5.28 & 4.11 & 4.352 & $<0.001$ \\
\hline Personal achievement / Poczucie osiągnięć osobistych (PA) & medium / średni & 34.36 & 7.46 & 36.39 & -3.336 & 0.001 \\
\hline
\end{tabular}

sample. In turn, the level of depersonalization in the physiotherapist group was significantly higher than in the study by Pasikowski $(p<0.001)$. Significant differences were also recorded in the level of personal accomplishment $(\mathrm{PA})$, it was lower in the present study (mean $(\mathrm{M})=34.36)$ than in the standardization sample $(\mathrm{M}=36.39)$.

On the basis of the reference levels included in the manual for the MBI questionnaire (20), it may be assumed that, in the group of physiotherapists, emotional exhaustion and personal accomplishment reached their average level, while depersonalization was at a low level.

Analysis of the dependency of burnout indicators and demographic variables was presented in Table 3. There were no statistically significant relationships between the subjects' age and the level of burnout indicators $(p>0.05)$. Empirical data pointed to statistically significant range differences in terms of depersonalization and personal achievement in subgroups divided according to gender. Results confirmed that men, more than women, experienced depersonalization and they were less satisfied with their professional accomplishments. Due to large differences in the size of both groups, analysis of the relationships between the variables of gender and burnout among physiotherapists calls for caution and further verification.

The obtained results suggested that the level of education is connected with professional burnout in physiotherapists (Table 3). The people with university degrees experienced higher level of personal accomplishment $(\mathrm{M}=35.33)$ than physiotherapists with a lower level of education $(\mathrm{M}=32.81)$.

Analysis of the data did not confirm the relationship between marital status, having children and burnout (Table 3). Although, divorced people demonstrated higher results in terms of emotional exhaustion and depersonalization, and lower results concerning perception of personal achievement, differences did not reach the level of statistical significance.

Analysis of the dependency between burnout indicators and work-related variables were presented in Table 4. When regarding work experience, noteworthy variations concern the index of depersonalization which reached the highest values in the group of employees with 15-19 years of experience and the lowest level in physiotherapists working shorter than 5 years $(\mathrm{p}=0.036)$.

It was also verified that the level of occupational burnout in physiotherapists was connected with the place of employment and job character. Basing on the analysis of mean values, it can be observed that physical therapists employed in hospitals experienced the strongest emotional exhaustion and depersonalization. In spite of this fact, the level of personal achievement among hospital professionals did not differ from the results obtained by other therapists. A lower level of professional burnout was observed in physiotherapists employed in health centres.

The age of patients subject to therapy was also considered during analysis of the specific nature of physiotherapists' work and its effect on burnout indices. This criterion allowed for the separation of 2 groups: physiotherapists working with adults and those working with children. Considerable differences in these subgroups were observed for the level of emotional exhaustion and depersonalization. Professional burnout reached higher intensity in physiotherapists who work with adults (Table 4).

The focus of the analysis of physiotherapists' work was also on different workplaces. No direct relationships between the load typical of a workplace and the manifestation of burnout were confirmed ( $p>0.05)$. 
Table 3. Professional burnout indices in relation to demographic variables

Tabela 3. Zależność wskaźników wypalenia zawodowego od zmiennych demograficznych

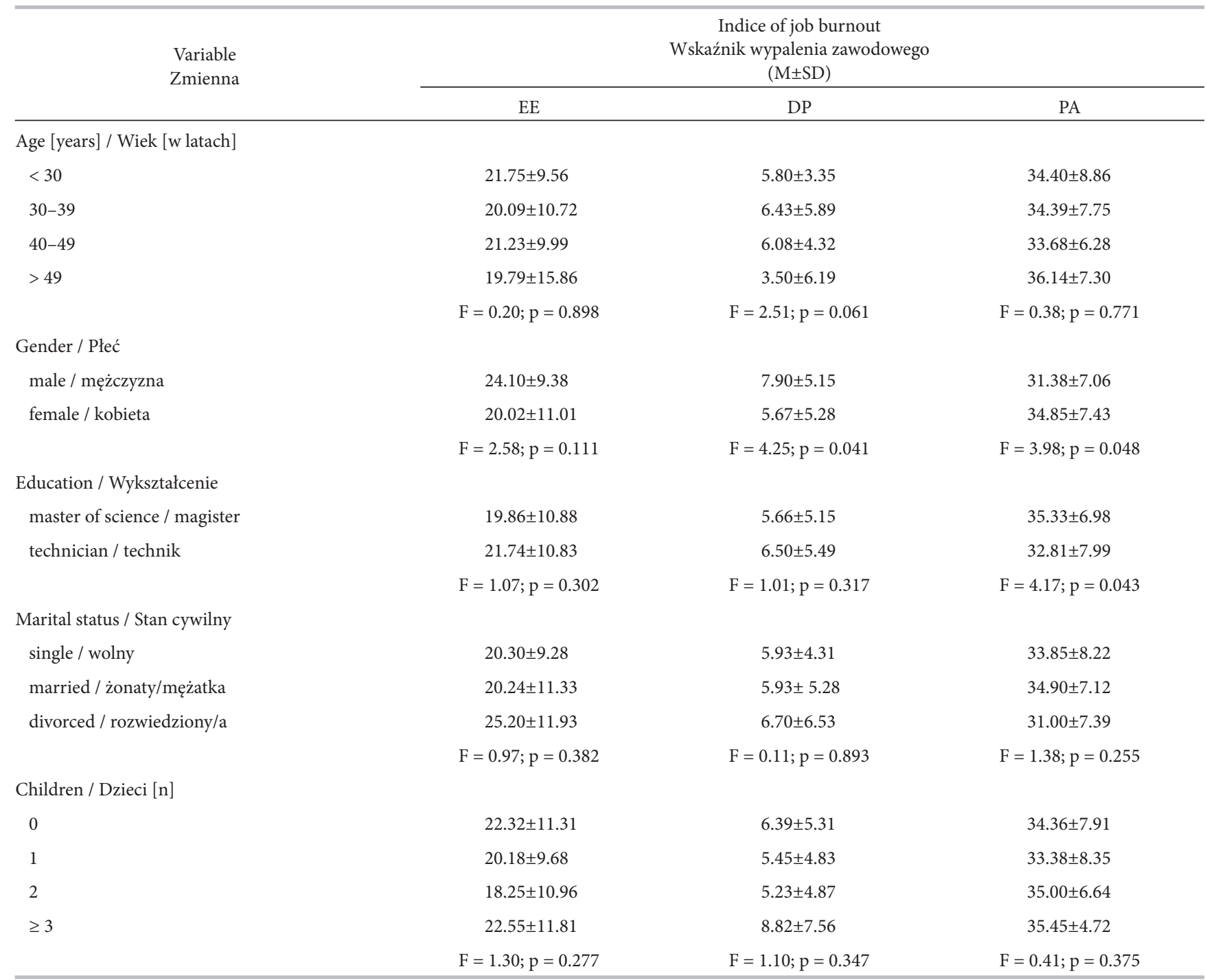

EE - emotional exhaustion / wyczerpanie emocjonalne, DP - depersonalization / depersonalizacja, PA - personal accomplishment / poczucie osiągnięć osobistych. Other abbreviations as in Table 2 / Inne skróty jak w tabeli 2.

Table 4. Professional burnout indices in relation to job-related variables

Tabela 4. Zależność wskaźników wypalenia zawodowego do zmiennych związanych z pracą

\begin{tabular}{lccc}
\hline \multirow{2}{*}{$\begin{array}{c}\text { Variable } \\
\text { Zmienna }\end{array}$} & \multicolumn{3}{c}{$\begin{array}{c}\text { Professional burnout indice } \\
\text { Wskaźnik wypalenia zawodowego } \\
\text { (M } \pm \text { SD) }\end{array}$} \\
\cline { 2 - 4 } $\begin{array}{l}\text { Work experience [years] / Staż pracy [w latach] } \\
<5\end{array}$ & $19.31 \pm 9.82$ & DP \\
$5-9$ & $18.0 \pm 8.80$ & $4.77 \pm 3.14^{*}$ & $35.54 \pm 7.40$ \\
$10-14$ & $21.12 \pm 10.71$ & $5.27 \pm 4.26$ & $35.68 \pm 7.40$ \\
$15-19$ & $24.32 \pm 11.79$ & $5.76 \pm 4.57$ & $31.97 \pm 8.01$ \\
$\geq 20$ & $20.58 \pm 12.33$ & $9.32 \pm 7.28^{*}$ & $33.79 \pm 7.37$ \\
& $\mathrm{~F}=1.49 ; \mathrm{p}=0.207$ & $4.83 \pm 4.90$ & $35.08 \pm 6.93$ \\
\hline
\end{tabular}


Table 4. Professional burnout indices in relation to job-related variables - cont.

Tabela 4. Zależność wskaźników wypalenia zawodowego do zmiennych związanych z pracą - cd.

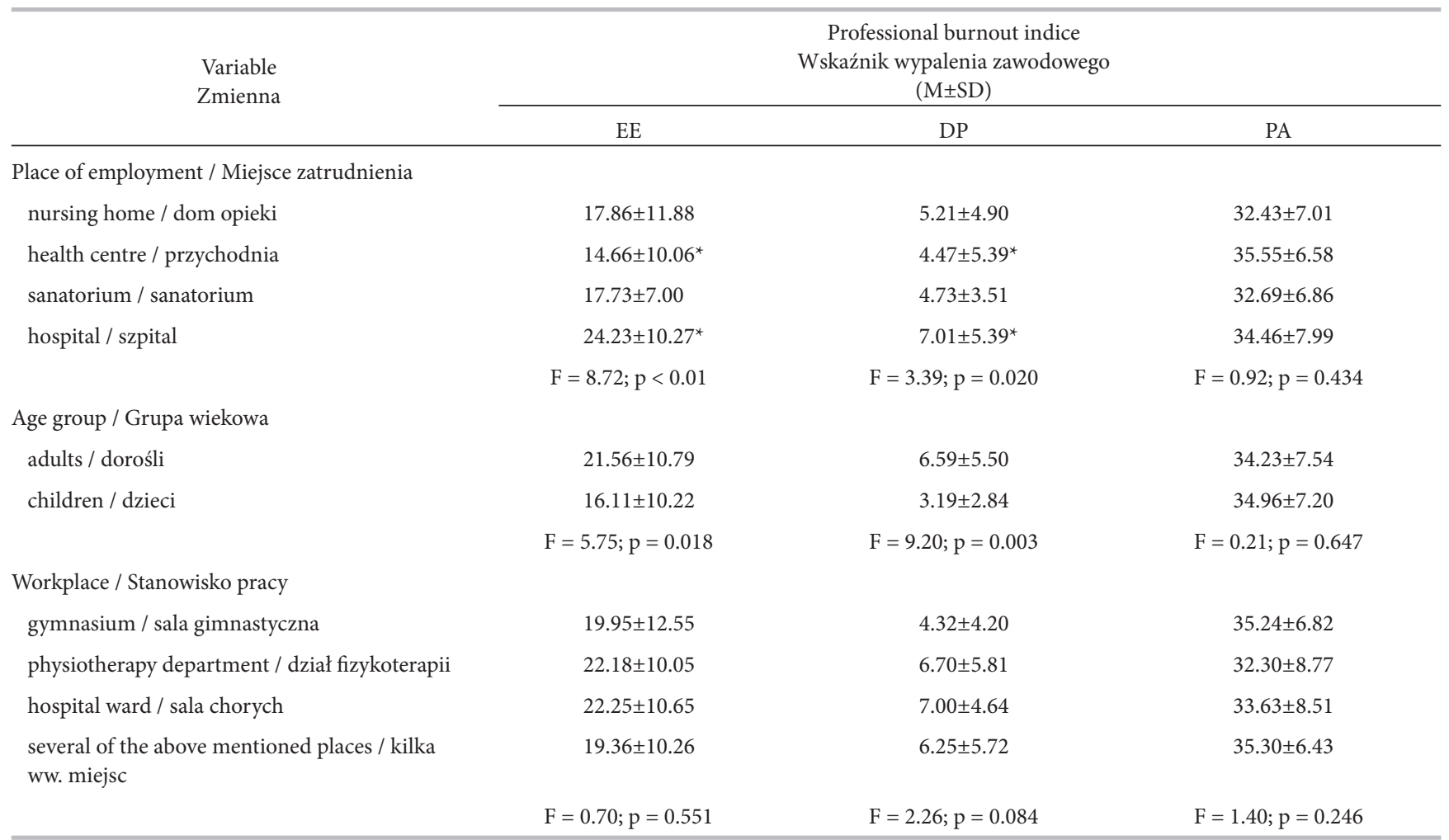

* Pairs of variables containing significant differences in the Tukey test / Pary zmiennych, w których wykazano istotne różnice w teście Tukeya.

Abbreviations as in Table 2 / Skróty jak w tabeli 2.

\section{DISCUSSION}

The goal of the investigation was to verify the degree of intensity and specific nature of the phenomenon of professional burnout among the group of physiotherapists. Lack of Polish norms for the MBI creates great difficulties in interpreting the results obtained, with which many researchers in Poland are faced. Due to the increasing interest in the problem of burnout, the development of Polish norms for the MBI becomes a very important issue, it should be taken into account in future studies.

In the present study, burnout indicators were related to the levels of reference specified by authors of the MBI. On this basis, it was found that burnout in physiotherapists is manifested by an increased level of emotional exhaustion and a decreased level of personal accomplishment, but little is manifested in depersonalization. However, due to the fact that quoted reference levels were not based on Polish population, these analyzes can not be the basis for drawing substantive conclusions.

Referring the authors' arch to the results of teachers and nurses in Pasikowski's study (19), it can be stated that physiotherapists experienced higher depersonalization and lower personal accomplishment. Data from other comparative studies has shown that health professionals may differ in the degree of severity and specificity of burnout. Li Calzi et al. (9) found that emotional exhaustion was the highest in physiotherapists, depersonalization among doctors, while the lowest level of personal accomplishment was observed in technicians. Interesting results were obtained by Makara-Studzińska et al. (21), who evaluated the level of burnout in a group of Polish female pharmacists and physiotherapists with the Burnout Inventory Scale by Steuden and Okła. Their results demonstrated that the level of burnout (both in general terms and in the five subscales) were significantly higher in physiotherapists, it was also associated with a significantly lower life satisfaction in this group. On the basis of the authors' own studies and cited reports, it can be concluded that burnout can concern health officials at varying degrees. Therefore, accurate knowledge of the determinants of burnout in Polish physiotherapists, thus more extensive research, should be the goal for the future. 
Analysis of demographic variables and factors connected with work allowed to separate factors connected with burnout indices in physiotherapists. Individuals stereotypically assume that women are more susceptible to stress and burnout. Literature shows lack of unequivocal conclusions about the effect of gender on the level of intensity of occupational burnout (4). The study did not substantiate the speculation that burnout occurs more frequently among women. However, as could be confirmed by the theory, the burnout syndrome differently manifested in men and women. Empirical data points out that women are put at a higher risk of emotional exhaustion due to their higher sensitivity and tendency to get involved in patients' problems (22). Any risk of burnout increases with depletion of one's own emotional resources and also occurs in areas outside the workplace, which specifically concerns women burdened with family duties. However, some investigation and the obtained results verify that women may not be as vulnerable to burnout as previously reported. This might result from individual factors, such as personality or coping strategies.

The level of depersonalization turned out to be higher in the studied men, but men constituted a small percentage of the study group, thus this level should be interpreted with caution. Previous studies confirm that men are more likely to experience depersonalization than women $(12,22)$. It is estimated that an important element which differentiates the specific nature of burnout in women and men is a difference in social expectations connected with gender. The traits traditionally attributed to men, such as strength, independence, professional achievement and invulnerability, might be more conducive to an instrumental approach to patients and intensify impersonal attitudes (dehumanization) (22).

Brown (23) shows that doing traditionally female jobs by men is associated with their low social position. This results from the fact that social work is frequently connected with low remuneration and prestige, which seem to be particularly important to men. For these reasons, men working in health service experience a reduced feeling of personal accomplishment, which is also confirmed by the results of the authors' own investigation.

In considering the effect of marital status on job burnout, it is difficult to draw direct conclusions. No significant relationships between the indices of burnout and marital status were observed in the studied group, which is concurrent with numerous reports $(4,24)$. A number of publications, however, have demonstrated a relationship between marriage and success or professional burnout.
Data from the related literature indicates that single people are more susceptible to burnout than married ones. Furthermore, the results obtained by Maslach et al. (1) confirm that people who have never been married experience higher professional burnout than the divorced. The same authors showed that having children is connected with low level of emotional exhaustion and depersonalization. Our study, however, did not confirm the relationship between the number of children and the level of burnout indicators. Attempts to explain these differences emphasize the role of individual variables that determine the marital status of the employees, which are also essential for professional burnout (1).

Physiotherapists with lower qualifications experience a reduced feeling of personal accomplishment. It can be assumed that well-educated professionals, showing higher therapeutic skills, might much more frequently feel satisfied with the results of their work (25). On the other hand, experienced and well-educated therapists are employed at more responsible and more stressful positions, which might cause emotional exhaustion (1). This was not confirmed in the present study as there were only a few people who performed managerial jobs, whereas other physiotherapists worked at similar positions, regardless of the level of education.

The level of professional burnout among physiotherapists considerably depends on the health institutions they are employed in. Emotional exhaustion and depersonalization concern, to a lesser extent, physiotherapists who work in health centres, whereas the highest values are reached by hospital employees. This is connected with the type of difficulties the staff are exposed to. In hospitals, cooperation focuses on dying, ill or disabled people, which is connected with higher physical and psychological strain. Hospitalized patients feel anxiety and fear, thus they expect particular interest and support (26). High strain with patients' problems contributes to the release of defence mechanisms, which in consequence, might lead to depersonalization. This is confirmed by the fact that physiotherapists who carry out therapies only at patients' bedsides, directly in hospital wards, are characterized by the highest level of emotional exhaustion and depersonalization. It should be emphasized that working for public health service does not only involve higher strain but also lower satisfaction, which also impacts the increased risk of professional burnout (10). Research by Kowalska (27) showed that the level of burnout indicators may also be associated with other organizational variables. In the cited study, physiotherapists working with neurological 
and orthopedic patients experienced higher levels of emotional exhaustion, and the depersonalization level was significantly higher in people using kinesitherapy.

The authors' own investigation confirms that people who work with children experience lower emotional exhaustion and depersonalization than those who work with adults. This is contrary to the research of Pavlakis et al. (10) who reported that working with younger patients, particularly with children, tends to be more distressing. Under conditions of high stress, professional satisfaction is said to be an element of protecting workers against adverse effects of strain. Research by Kowalska (27) confirms that physical therapists working with children achieved a higher level of satisfaction with their achievements. The present study did not analyse the effect of professional satisfaction on burnout indices, which should be taken into consideration in further projects.

Numerous surveys have shown that younger and less experienced workers are more at the risk of professional burnout $(1,28)$. This phenomenon can be connected with different responses to stressful situations and the ability to cope with stress among workers with different work experience.

The surveys suggest that more experienced workers demonstrate better abilities to cope with stress and thus, they are at a lower risk of burnout. In the authors' own study, it was found that work experience considerably determines only depersonalization, which reached the highest level among employees with 15-19 years of experience. It can be expected that long-lasting exposure to stressful conditions and susceptibility to fatigue, which intensifies with age, can explain the tendencies revealed during the investigation.

The least burnt-out physiotherapists worked less than 5 years, which is at variance with the research which reported frequent occurrences of burnout in younger workers who have difficulties satisfying the needs of patients, experience stress to a higher extent and are more critical in relation to their work. The results obtained in the study might have been affected by the fact that the employees who burnt-out at the initial stages of their careers frequently gave up their jobs and only the people who exhibited a lower level of burnout continued working (4). It should be emphasized that the criteria adopted for selection prevented the inclusion of employees whose work experience was shorter than 3 years. This caused a low number of participants in the subgroup with the shortest work experience and might have affected the obtained results.

\section{CONCLUSIONS}

The study confirmed that physiotherapists, similarly to other employees in health service, may be exposed to professional burnout. However, due to the lack of Polish norms for the MBI, it is difficult to accurately estimate the severity of this phenomenon. Men, less-educated therapists and those who work in hospitals are more afflicted by this phenomenon. Due to the small number of men, a conclusion concerning the relationship between gender and burnout indicators should be verified in future studies on physiotherapists.

The essential effect on burnout among physiotherapists is also from other factors which were not included in the present study. Therefore, it seems necessary to carry out further investigation in order to recognize environmental and psychological determinants of this complex phenomenon among workers who are responsible for physical therapy sessions. Examples include more organizational and work related factors, coping with stress and personality traits. The results obtained in the future might have practical implications for the isolation of the physiotherapists threatened with professional burnout and implementation of prevention programmes aimed at minimizing the costs generated either by the absence of employees or by work-related health problems.

\section{REFERENCES}

1. Maslach C, Schaufeli WB, Leiter MP. Job burnout. Ann Rev Psychol. 2001;52:397-422, http://dx.doi.org/10.1146/ annurev.psych.52.1.397.

2. Zhang Y, Feng X. The relationship between job satisfaction, burnout, and turnover intention among physicians from urban state-owned medical institutions in Hubei, China: A cross-sectional study. BMC Health Serv Res. 2011;11:235, http://dx.doi.org/10.1186/1472-6963-11-235.

3. Scanlan JN, Still M. Job satisfaction, burnout and turnover intention in occupational therapists working in mental health. Aust Occup Ther J. 2013;60(5):310-8.

4. Balogun JA, Titiloye V, Balogun A, Oyeyemi A, Katz J. Prevalence and determinants of burnout among physical and occupational therapists. J Allied Health. 2002;31(3):131-9.

5. Santos MC, Barros L, Carolino E. Occupational stress and coping resources in physiotherapists: A survey of physiotherapists in three general hospitals. Physiotherapy. 2010;96(4):303-10, http://dx.doi.org/10.1016/ j.physio.2010.03.001.

6. Park JR, Coombs C, Wilkinson AJ, Loan-Clark J, Arnold J, Preston D. Attractiveness of physiotherapy in the 
National Health Service as a career choice: Qualitative study. Physiotherapy. 2003;89(10):575-83, http://dx.doi. org/10.1016/S0031-9406(05)60056-9.

7. Broom JP, Williams J. Occupational stress and neurological rehabilitation physiotherapists. Physiotherapy. 1996;82(11): 606-14, http://dx.doi.org/10.1016/S0031-9406(05)66329-8.

8. Enberg B, Nordin C, Öhman A. Work experiences of novice occupational therapists and physiotherapists in public sector employment: Analyses using two occupational stress models. Adv Physiother. 2010;12(1):42-9, http://dx.doi.org/10.3109/14038190903033161.

9. Li Calzi S, Farinelli M, Ercolani M, Alianti M, Manigrasso V, Taroni AM. Physical rehabilitation and burnout quantification of its: Different aspects of the syndrome and comparison between healthcare professionals involved. Eur Med Phys. 2006;42(1):27-36.

10. Pavlakis A, Raftopoulos V, Theodorou M. Burnout syndrome in Cypriot physiotherapists: A national survey. BMC Health Serv Res. 2010;10:63, http://dx.doi.org/ 10.1186/1472-6963-10-63.

11. Eivazi M, Alilou A, Fereidounnia S, Zaki Z. Factors associated with burnout syndrome in physiotherapy staff: A questionnaire study. Health Med. 2013;7(1):304-12.

12. Fischer M, Mitsche M, Endler PC, Mesenholl-Strehler E, Lothaller H, Roth R. Burnout in physiotherapists: Use of clinical supervision and desire for emotional closeness or distance to clients. Int J Ther Rehabil. 2013;20(11):550-8, http://dx.doi.org/10.12968/ijtr.2013.20.11.550.

13. Martinussen M, Borgen PC, Richardsen A. Burnout and engagement among physiotherapists. Int J Ther Rehabil. 2011;18(2):80-8,http://dx.doi.org/10.12968/ijtr.2011.18.2.80.

14. Ogiwara S, Hayashi H. Burnout amongst physiotherapists in Ishikawa Prefecture. J Phys Ther Sci. 2002;14(1): 7-13, http://dx.doi.org/10.1589/jpts.14.7.

15. Strzelecki Z, Błędowski P, Gałązka A, Nowak L, Kowalska I, Kurkiewicz J, et al. [The demographic situation of Poland. Report 2011-2012]. Warszawa 2012 [cited 2014 Jan 13]. Available from: http://old.stat.gov.pl/Raport.pdf. Polish.

16. Lindsay R, Hanson L, Taylor M, McBurney H. Workplace stressors experienced by physiotherapists working in regional publichospitals. Aust J Rural Health.2008;16(4):194200, http://dx.doi.org/10.1111/j.1440-1584.2008.00980.x.

17. Strulik H. Pensions and productivity: The economic impact of an ageing population. SCOOP Project: So- cial-economic and Humanities Research for Policy [cited 2014 Jan 13]. Available at: http://www.scoopproject. org.uk/Data/Sites/1/media/july12_printable.pdf.

18. Narumoto J, Nakamura K, Kitabayashi Y, Shibata K, Nakamae T, Fukui K. Relationships among burnout, coping style and personality: Study of Japanese professional caregivers for elderly. Psychiatry Clin Neurosci. 2008;62(2):174-6, http://dx.doi.org/10.1111/j.1440-1819. 2008.01751.x.

19. Pasikowski T. [Polish adaptation of the Maslach Burnout Inventory]. In: Sęk H. [Job burnout: Causes and prevention]. Warszawa: PWN; 2012. Polish.

20. Maslach C, Jackson SE, Leiter M. Maslach Burnout Inventory Manual. 3 ed. Palo Alto: Consulting Psychologists Press; 1996.

21. Makara-Studzińska M, Kryś-Noszczyk K, Starczyńska M, Kiebzak W, Śliwiński Z. [Burnout and life satisfaction of women working in the profession physiotherapist profession]. Fizjoter Pol. 2012;12(4):327-39. Polish.

22. Purvanowa RK, Muros JP. Gender differences in burnout: A meta-analysis. J Vocat Behav. 2010;77(2):168-85, http://dx.doi.org/10.1016/j.jvb.2010.04.006.

23. Brown GT. The male minority: Job satisfaction of men in occupational therapy. Work. 1995;5(1):51-69, http://dx.doi.org/10.3233/WOR-1995-5110.

24. Norlund S, Reuterwall C, Höög J, Lindahl B, Janlert U, Birgander LS. Burnout, working conditions and gender-results from the northern Sweden MONICA Study. BMC Public Health. 2010;10:326, http://dx.doi.org/ 10.1186/1471-2458-10-326.

25. Payne N. Occupational stressors and coping as determinants of burnout in female hospice nurses. J Adv Nurs. 2001;33(3):396-405, http://dx.doi.org/10.1046/ j.1365-2648.2001.01677.x.

26. Tobiasz-Adamczyk B. [Physician-patient relationships from the perspective of medical sociology]. Kraków: Wydawnictwo Uniwersytetu Jagiellońskiego; 2002. Polish.

27. Kowalska J. [Professional burnout among Polish physiotherapists]. Post Rehab. 2011;3:43-52. Polish.

28. Oyefeso A, Clancy C, Farmer R. Prevalence and associated factors in burnout and psychological morbidity among substance misuse professionals. BMC Health Serv Res. 2008;8:39, http://dx.doi.org/10.1186/1472-6963-8-39.

The use of the article „Burnout syndrome in physical therapists - demographic and organizational factors” is permitted under license conditions of Creative Commons Attribution-NonCommercial 3.0 (also known as CC-BY-NC), available at http://creativecommons.org/licenses/by-nc/3.0/pl/ or another language version of this license or any later version of this license published by Creative Commons / Zezwala się na korzystanie z artykułu „Zespó 1 wypalenia zawodowego u fizjoterapeutów a zmienne demograficzne i organizacyjne" na warunkach licencji Creative Commons Uznanie autorstwa Użycie niekomercyjne 3.0 (znanej również jako CC-BY-NC), dostępnej pod adresem http://creativecommons.org/licenses/by-nc/3.0/pl/ lub innej wersji językowej tej licencji, lub którejkolwiek późniejszej wersji tej licencji, opublikowanej przez organizację Creative Commons. 